\section{Research Square}

Preprints are preliminary reports that have not undergone peer review.

They should not be considered conclusive, used to inform clinical practice, or referenced by the media as validated information.

\title{
Bacterial morphotypes as biodiversity indicators in a scarcely explored ecosystem in Santiago de Cali, Colombia
}

\author{
Laura Vergara-López \\ Universidad Santiago de Cali \\ Alejandro Díaz-Ortíz \\ Universidad Santiago de Cali \\ Doris Rosero-García ( $\sim$ doris.rosero00@usc.edu.co) \\ Universidad Santiago de Cali
}

\section{Research Article}

Keywords: leachate treatment, culturable bacteria, morphotypes, ecosystems

Posted Date: December 15th, 2020

DOI: https://doi.org/10.21203/rs.3.rs-125959/v1

License: () (1) This work is licensed under a Creative Commons Attribution 4.0 International License. Read Full License 


\section{Abstract}

Bacteria are considered as the most diverse microorganisms on earth. However, bacterial diversity is unknown in some ecosystems, such as leachate treatment plants. In the present study, we characterized culturable bacteria isolated from six lagoons and one pure leachate to assess whether bacterial morphotypes can be used as biodiversity indicators. The sampling site was a leachate treatment plant located in Santiago de Cali. Overall, 311 bacterial morphotypes were collected from six lagoons, and a pure landfill leachate, and were identified using colony characters. Four biodiversity indexes related to species richness and abundance as well as to the estimation of the number of species present were calculated. The results show a great diversity of bacterial morphotypes in all samples. Further, the highest estimates of biodiversity were observed at lagoon 6 physicochemically treated, and the lowest estimates were observed at lagoons 5 and 8 . The leachate generated in the sampled lagoons, which were composed of different elements, allows for the colonization of diverse bacteria. Moreover, these bacteria were resistant to the treatment plant processes, thereby explaining the highest diversity observed at the lagoon 6. Our results showed that bacterial morphotypes can be used as biodiversity indicators in ecosystems.

\section{Introduction}

Colombia is considered a vastly diverse country with a great diversity of flora and fauna ${ }^{1-3}$. Mountainous ecosystems and tropical forests extensively contribute to the biodiversity of the country, where approximately 58,312 species have been recorded without considering the enormous diversity of microorganisms ${ }^{4}$. Currently, a list of 100 bacterial species registered in Colombia was published ${ }^{5}$. Bacteria are organisms that belong to the domain Bacteria and have been found in different environments ${ }^{6}$. In Colombia, studies in bacterial isolates from soil ${ }^{7}$ air $^{8}$, and water ${ }^{9}$ have been performed. However, the presence of bacteria and their diversity in some areas remain unknown. An example of these ecosystems is the leachate treatment plant located in the Antiguo Vertedero de Navarro (old Navarro landfill), a place of environmental importance because it was a landfill for $>40$ years. Since 2014 , the plant has been in operation to collect and conduct leachates to the treatment system and subsequently manage leachates through physicochemical treatments ${ }^{10}$.

Biodiversity is a measure of variation between different organisms and is classified into three levels: genes, species, and ecosystems ${ }^{11,12}$. There are mathematical operations for the estimation of alpha, gamma, and beta biodiversity ${ }^{13,14}$. Alpha diversity quantifies species richness in a community and beta diversity estimates the degree of species differentiation at a certain geographic site. Further, gamma diversity is the richness of species in a community integrating the landscape ${ }^{15}$.

In ecology, the most used indexes are Simpson (D) and Shannon-Wiener $\left(\mathrm{H}^{\prime}\right)^{16}$, which have been applied in biodiversity studies in different organisms such as plants ${ }^{17,18}$, mosquitoes ${ }^{19,20}$, and fungi isolated from soil ${ }^{21,22}$. The $D$ index reflects the heterogeneity of the sample considering two factors, the number of species and their relative abundance ${ }^{23}$. This index has been commonly used in the analysis of the species richness of bacteria of clinical and environmental interest that have been identified up to genus and/or species level using molecular techniques ${ }^{24-26}$. In Aquixtla, Mexico, the diversity of Enterobacteria present in soil and in tomatoes was evaluated in three greenhouses that used a fertigation system. Three indexes were estimated: the $\mathrm{H}^{\prime}$ index indicated differences in the microbiota, the $\mathrm{D}$ index showed that few species are predominant in this bacterial community, and the Chao index (SChao1) showed a greater abundance of Enterobacter cloacae in tomatoes from the three greenhouses ${ }^{27}$. In another study, the structure of a cultivable heterotrophic bacterial community was evaluated in samples obtained from three sampling sites of the Almendares River in La Habana, Cuba. The D and H' indexes showed significant differences in the bacterial diversity at the three sampling sites ${ }^{28}$. In Colombia, 1,060 microbial morphotypes (bacteria and fungi) were isolated from Los Nevados National Natural Park; the morphotypes were macroscopically and microscopically characterized as well as analyzed using 16S rDNA sequencing ${ }^{7}$. In the mentioned studies, bacteria were evaluated as estimates of biodiversity and were identified at the genus and/or species level. However, to date, to the best of our knowledge, no studies on the use of bacterial morphotypes as biodiversity indicators when bacteria were only macroscopically and microscopically characterized have been conducted. Therefore, in the present study, four biodiversity indexes were evaluated to determine whether the bacterial morphotypes isolated from a leachate treatment plant can be useful as biodiversity indicators. This study contributes to the knowledge of microorganism biodiversity in a scarcely explored ecosystem that currently benefits the city of Santiago de Cali, Department of Valle del Cauca, and the country itself.

\section{Methods}

\section{Study site and morphotypes determination}

The Antiguo Vertedero de Navarro is located in the southwest of Colombia in the city of Santiago de Cali, Department of Valle del Cauca (Figure 1). Sampling was performed from March to October 2019 using a methodology described for conducting rapid biodiversity inventories ${ }^{55}$. The plant was visited three times and each lagoon was divided into quadrants (3-6) depending on the structure and access. Moreover, samples were collected from a pure leachate located diagonally to the leachate treatment plant. Leachate samples were collected in sterile bottles and transported to the microbiology laboratory of the Universidad Santiago de Cali. Serial dilutions from $10^{-3}$ to $10^{-6}$ were prepared using nutritive agar as the culture medium to identify the largest possible number of bacterial morphotypes. Bacteria were plated in triplicates and grown for $48-72 \mathrm{~h}$ at room temperature ${ }^{56}$. Bacterial morphotypes were identified using taxonomic characteristics such as color, form, size, elevation, surface, margin, and texture

57. Consecutive numbers were assigned to each morphotype, and Gram staining and spore staining were performed, last in gram-positive bacilli only. 
The results were recorded in an Excel 2016 file. Additionally, a photographic record for each of the morphotypes was obtained. Morphotypes were stored in $1.5-\mathrm{mL}$ tubes with nutrient broth and skim milk agar at $-20^{\circ} \mathrm{C}$.

\section{Biodiversity analysis}

Four indexes were used to estimate the alpha biodiversity from bacterial morphotypes. The Simpson index of diversity or dominance, calculated as $\mathrm{D}=\sum p_{i}^{2}(1)$, evaluates the probability that two individual samples collected at random belong to the same species ${ }^{58}$. In the present study, this corresponds to the probability that two bacterial morphotypes collected at random have the same morphotype. The Shannon index of species richness, calculated as $\mathrm{H}^{\prime}=-\sum p_{i} \operatorname{Ln} p_{i}(2)$, assumes that the individual samples are randomly selected and are all represented in the sample 58 . Therefore, the number of morphotypes present in a sample (species richness) and the relative number of individuals of each morphotype (abundance) are considered. The Pielou's species evenness index, calculated as $J=\frac{H}{\operatorname{Ln}(S)}(3)$, estimates the proportion of the observed diversity in relation to the expected maximum ${ }^{58}$. In the present study, we evaluated whether the morphotypes in the samples are equally abundant or whether some

morphotypes are present in a greater abundance than the others. The non-parametric index, calculated as $C h a o 1=S+\frac{a^{2}}{2 b}(4)$, estimates the number of species in the sample based on the number of species represented by one individual and the number of those represented by two individuals ${ }^{59}$. This index was applied to estimate the number of morphotypes that should be present in the different lagoons. In the equations, $S$ represents the number of bacterial morphotypes present in a sample, the proportional abundance of the morphotypes divided by the total number of morphotypes, a is the number of species represented by one individual, and $b$ is the number of species represented by two individuals.

\section{Results}

\section{First item}

Overall, 765 isolates were obtained. After careful examination, 311 bacterial morphotypes showing differences in form, elevation, margin, and color were identified (Figure 2, Table 1). Some of these morphotypes were reported in an educational booklet addressed to the university community of the Universidad Santiago de Cali ${ }^{29}$. Only 3 of the 311 morphotypes were present in the 6 sampled lagoons and the pure leachate. These morphotypes were assigned the numbers 34,38 , and 41 . The morphotypes 38 and 41 were collected at all 3 samplings (March, August, and October), whereas morphotype 34 was collected in the August and October samplings. Typically, a high number of morphotypes was observed, ranging from 8 to 19 in March 14 to 63 in August, and 16 to 55 in October (Figure 3). Gram staining showed that most morphotypes were gram-positive [76.2\% (236/311)], whereas a lesser extent of gram-negative morphotypes [4.8\% (16/311)] and gram-variable morphotypes [19\% (58/311)] were observed (Figure 3, Table 1). Bacilli was the predominant microscopic form (186/311). Additionally, $92.5 \%(172 / 188)$ of the gram-positive bacillary morphotypes produced spores, whereas $7.5 \%(14 / 188)$ did not produce spores.

\section{Second item}

The diversity indexes obtained according to lagoon and sampling date are presented in Table 2. A Simpson index (D) close to 0 indicates a greater diversity in the sample. Lagoon 6 presented the highest estimation of diversity in the global analysis, particularly in the second and third samplings (Table 2). Shannon index $\left(\mathrm{H}^{\prime}\right)$ values <2 represent low diversity, whereas values $\geq 3$ represent a high diversity in the sample. In the first sampling occasion, all the studied lagoons showed low diversity, whereas in the second sampling occasion, lagoons 5 and 6 presented high diversity. In the third sampling, lagoons 4, 5, and 8 showed low diversity, and in the global analysis lagoons 5 and 8 showed low diversity. Moreover, lagoon 6 had the highest diversity according to the Shannon index ( $\left.\mathrm{H}^{\prime}\right)$ (Table 2). A Pielou's index ( $\mathrm{J}$ ) close to 0 represents little evenness in the sample, and a value of 1 represents total evenness. At the first sampling, all the results showed little evenness. At the second sampling, lagoon 6 and the pure leachate presented high evenness, indicating that the abundance of the different bacterial morphotypes present in these lagoons is evenly distributed. At the third sampling as well as in the global analysis, lagoon 6 showed the largest evenness. However, lagoons 5 and 8 presented low evenness at the third sampling and in the global analysis (Table 2). For the Chao1 index, we hypothesized the presence of numerous bacterial morphotypes. However, the estimation of numerous bacterial morphotypes was not possible in the first sampling from lagoons 5 and 7 and the third sampling from lagoon 4 . The Chao1 index is based on the morphotypes represented by one individual and the morphotypes represented by exactly two individuals. In the present study, the equation could not be applied because values of 0 were found. According to this index, it was estimated that, in the first, second, and third sampling occasions, lagoon 3, lagoon 8, and pure leachate would have the highest amount of morphotypes, respectively. In the global analysis, lagoon 7 was estimated to present the highest number of bacterial morphotypes (Table 2). Cumulatively, these results suggest that lagoons 3,7 , and 8 and the pure leachate provided the highest number of bacterial morphotypes in the study site.

\section{Discussion}

Bacteria are the most abundant microorganisms in the world and their diversity has not yet been completely elucidated ${ }^{30-34}$. In the environmental field, bacteria have been useful in the analysis of water quality ${ }^{35,36}$, in the evaluation of soil contamination ${ }^{37,38}$, and as the indicators of food quality ${ }^{39,40}$. Regarding biodiversity, studies on the diversity of bacterial communities in treatment plants have identified bacterial genera and/or species ${ }^{41,42}$. In addition, in a recent report, bacterial morphotypes were used as biodiversity indicators in moorland ecosystems in Colombia. However, in that study, the 
morphotypes were identified using conventional bacterial taxonomic characteristics and 16S rDNA sequences ${ }^{7}$. In the present study, bacterial morphotypes only macroscopically and microscopically identified were evaluated. Although bacteria were not identified at the genus and/or species level, our results demonstrate that bacterial morphotypes can be used as biodiversity indicators. The inference is based on the fact that the bacterial morphotypes identified in the lagoons and pure leachate are characterized based on different taxonomic characteristics, rendering them different from each other. Morphotypes 34, 38, and 41 were identified as dominant morphotypes because they were found in all samplings. However, this represents a minimal percentage because each lagoon and the pure leachate contain unique morphotypes, which are representatives of their own biodiversity. In addition, our results allowed the evaluation of two indexes related to species richness (Simpson and Shannon), one index related to the evenness of the bacterial morphotype distribution (Pielou's), and the Chao1 index, an estimator of the number of species.

The Simpson index showed that there is high diversity among bacterial morphotypes in the six sampled lagoons and the pure leachate, showing that these microorganisms are present throughout the treatment plant contributing to its operation. Reportedly, a high bacterial diversity indicates that the bacterial community is in constant interaction defining inter- and intra-specific relationships for the functioning of the ecosystem 43,44 . In the sampled lagoons and the pure leachate, we consider the role of bacteria to be crucial for the operation of the treatment plant.

The global analysis results of the Shannon species richness index suggested that lagoon 6 is the most diverse, i.e., the one presenting the largest number of morphotypes. This is important because this lagoon is supplied with the waste that the leachate treatment plant cannot process. In addition, evaporation occurs in this lagoon, and the lagoon is subjected to physicochemical treatments that bacteria could use as a nutrient source. Bacteria present in lagoons 3, 5, 7, and 8 (lagoons for the collection and conduction of leachate to the plant) may be resistant to physicochemical treatments, resulting in a higher diversity in lagoon 6 . Further, these results suggested that the resident bacteria were able to degrade pollutants that were not degraded by the previous chemical treatment ${ }^{45,46}$. Most of the isolated morphotypes were gram-positive spore-forming bacilli. This is in contrast to previous studies performed in this type of ecosystems where gram-negative bacteria were the main representatives ${ }^{47-49}$. Spore-forming bacteria may be advantageous compared with non-spore-forming ones, considering that under adverse conditions, they can form spores to protect themselves until the appropriate conditions for growth and development are present ${ }^{50,51}$.

According to the results of the global analysis of the Pielou's evenness index, all bacterial morphotypes were evenly distributed in the studied lagoons, except for lagoons 5 and 8. Although the Simpson index indicated a diverse bacterial population, the bacterial morphotypes were not evenly distributed in these lagoons. Consequently, these lagoons presented the lowest values in terms of abundance and evenness of morphotypes. These results are important because they demonstrated that bacteria were not evenly distributed in an environmental matrix ${ }^{34}$. Besides the low diversity of bacterial morphotypes in lagoons 5 and 8, these results indicated that some of the morphotypes were present in a higher proportion than the others, suggesting that these lagoons, which collect leachate and are not subjected to any treatment, present optimal conditions for the development of certain bacteria that has the ability to produce metabolic waste that limits the growth of other bacteria or that limit the nutrients from their environment when optimally developed, thereby hindering further bacterial colonization ${ }^{52}$.

The bacterial morphotype compilation described in the present study contributes to the knowledge of bacterial diversity in - scarcely explored ecosystems, such as the leachate treatment plant located in the Antiguo Vertedero de Navarro. Some studies have proposed the identification of bacterial phylotypes and determination of their abundance and ecological attributes $34,53,54$. In the present study, we proposed the use of bacterial morphotypes as biodiversity indicators because a wide morphotype diversity was observed in the six studied lagoons and the pure leachate. Moreover, the correct operation of the plant is probably attributed to the resident bacteria, which could be spore-forming extremophilic bacteria. Furthermore, because these morphotypes may represent bacterial species having the potential of degrading different compounds, further studies for the identification of genus and/or species as well as degradation studies are warranted. Finally, the results of this study and use of bacterial morphotypes as biodiversity indicators may constitute a valuable input for biodiversity, taxonomic, and systematics studies.

\section{Declarations}

Acknowledgments: We thank the members of Semillero de Investigación en Microbiología Ambiental Maryory Vanessa Diazgranados, Maryuris Machacado Salas, and Diana Carolina Rache for their assistance in the field and laboratory work. LIV received support as a research assistant at the Universidad Santiago de Cali and resources from the project 934-621119-319 funded to DRG. DRG received financial support for her postdoctoral research from the Ministerio de Ciencia, Tecnología e Innovación-Minciencias, Colombia (no. 811-2018). This work was funded by Universidad Santiago de Cali, Grant No. 934-621119-319 to DRG.

Authors' contributions: Field and laboratory work were performed by LIV and AOD. The first draft of the manuscript and data analysis and interpretation were performed by LIV. Study conception and design, data analyses, and critical revisions of the manuscript was performed by DRG.

Funding: This work was funded by Universidad Santiago de Cali, Grant No. 934-621119-319 to DRG.

Competing interests: The authors declare that they have no conflicts or competing interests.

Data availability: Not applicable

Ethics declarations: Not applicable 
Approval for animal experiments: Not applicable

Approval for human experiments: Not applicable

Consent to participate/Consent to publish: Not applicable

\section{References}

1. Rangel-Ch, J. La biodiversidad de Colombia. Palimpsestvs 5:292-304. http://revistas.unal.edu.co/index.php/palimpsestvs/article/view/8083. (2005).

2. Rangel-Ch, J. La biodiversidad de Colombia: significado y distribución regional. Rev Acad Colomb Cienc Ex Fis Nat 39, 176-200 (2015).

3. Arbeláez-Cortés, E. Describiendo especies: un panorama de la biodiversidad colombiana en el ámbito mundial. Acta Biol Colomb 18:165-178. http://www.redalyc.org/articulo.oa?id=319028010012. (2013).

4. SiB Colombia. Biodiversidad en cifras 2020. IOP Publishing Physics Web. https://sibcolombia.net/biodiversidad-en-cifras-2020. Accessed 3 July 2020. (2020).

5. SiB Colombia. Catálogo de la biodiversidad 2020. IOP Publishing Physics Web. https://catalogo.biodiversidad.co/search/full?kingdom=bacteria. Accessed 3 November 2020. (2020).

6. Madigan, M., Martinko, J., Bender, K., Buckley, D. \& Stahl, D. Classification and Nomenclature. In: Brock Biology of Microorganisms (15th edition). Pearson, pp 374-376. (2017).

7. Avellaneda-Torres, L. \& Torres-Rojas, E. Biodiversidad de grupos funcionales de microorganismos asociados a suelos bajo cultivo de papa, ganadería y páramo en el Parque Nacional Natural de los Nevados, Colombia. Biota Colomb. 16, 78-118 (2015).

8. Méndez-Puentes, C., Camacho-Suárez, J. \& Echeverry-Hernández, S. Identificación de bacterias y hongos en el aire de Neiva, Colombia. Rev. Salud Pública 17, 728-737 (2015)

9. Sanchez-Diazgranados, J. \& Henry-Lopez, C. Degradation of aldrin by Bacillus licheniformis, isolated from water and sediment from the Ciénaga Grande, Santa Marta, Colombia. Acta Biológica Colomb 17:67-76. http://www.scielo.org.co/scielo.php?pid=S0120548X2012000100005\&script=sci_arttext\&tlng=pt. (2012).

10. Garcia, P. Manejo y tratamiento de lixiviados en rellenos sanitarios: revisión bibliográfica y experiencia en Planta de Tratamiento de Lixiviados de Navarro. pp 1-15. https://repository.usc.edu.co/bitstream/20.500.12421/677/1/MANEJO Y TRA. (2019).

11. Maturo, F. Unsupervised classification of ecological communities ranked according to their biodiversity patterns via a functional principal component decomposition of Hill's numbers integral functions. Ecol. Indic. 90, 305-315 (2018).

12. Llorente, J. \& Michán, L. Biodiversidad y biología organísmica. Ludus Vitalis 18, 313-316 (2016).

13. Tukiainen, H., Kiuttu, M., Kalliola, R., Alahuhta, J. \& Hjort, J. Landforms contribute to plant biodiversity at alpha, beta and gamma levels. J. Biogeogr. 46, 1699-1710 (2019).

14. Jost, L. \& González-Oreja, J. Midiendo la diversidad biológica: más allá del índice de Shannon. Acta zoológica lilloana 3-14. http://www.lillo.org.ar/journals/index.php/acta-zoologica-lilloana/article/view/240. (2012).

15. Baselga, A. \& Rodríguez, C. Diversidad alfa, beta y gamma: ¿cómo medimos diferencias entre comunidades biológicas? Nov Acta Científica Compostel 26:39-45. https://revistas.usc.gal/index.php/nacc/article/view/6413. (2019).

16. Carmona-Galindo, V. \& Carmona, T. La diversidad de los análisis de diversidad. Bioma 14:20-28. http://digitalcommons.Imu.edu/bio_fac/28. (2013).

17. Belul, G., Valbona, H., Najada, K., Ndoc, F. \& Alban, I. Geographic distribution and diversity assessment in ex situ collection of albanian medicinal plants. CMAPSEEC 8:51. http://eprints.ugd.edu.mk/12844/1/Proceedings_of_VIII_CMAPSEEC.pdf\#page=52. (2014).

18. Soler, P., Berroterán, J., Gil, J. \& Acosta, R. Índice valor de importancia, diversidad y similaridad florística de especies leñosas en tres ecosistemas de los Ilanos centrales de Venezuela. Agron Trop 62:25-37. http://ve.scielo.org/scielo.php?script=sci_arttext\&pid=S0002-

192X2012000100003\&lng=es\&nrm=i. (2012).

19. Viveros-Santos, V. \& Sandoval-Ruiz, C. Spatio-Temporal Diversity of Mosquitoes1 from the Central Area of Puebla State, Mexico. Southwest. Entomol. 43, 357-367 (2018).

20. Lamidi, B., Alo, E. \& Naphtali, R. Mosquito species diversity and distribution in three riverine communities of Taraba State, North-Eastern Nigeria. IOSR J. Pharm. Biol. Sci. 12, 21-28 (2017).

21. Mahecha-Vásquez, G., Sierra, S. \& Posada, R. Diversity indices using arbuscular mycorrhizal fungi to evaluate the soil state in banana crops in Colombia. Appl. Soil Ecol. 109, 32-39 (2017).

22. Samaniego-Gaxiola, J. \& Chew-Madinaveitia, Y. Diversidad de géneros de hongos del suelo en tres campos con diferente condición agrícola en la laguna, México. Rev. Mex. Biodivers. 78, 383-390 (2007).

23. Pla, L. Biodiversidad: Inferencia basada en el índice de Shannon y la riqueza.Interciencia 31:583-590. http://www.redalyc.org/articulo.oa? $\mathrm{id}=33911906$. (2006).

Page $5 / 9$ 
24. Roesch, L., Passaglia, L., Bento, F., Triplett, E. \& Camargo, F. Diversity of diazotrophic endophytic bacteria associated with maize plants. Rev. Bras. Ciência do Solo 31, 1367-1380 (2007).

25. Samsudin, A., Evans, P., Wright, A. \& Al Jassim, R. Molecular diversity of the foregut bacteria community in the dromedary camel (Camelus dromedarius). Environ. Microbiol. 13, 3024-3035 (2011).

26. Harris-Ricardo, J. et al. Perfil bacteriano del biofilm dental supragingival en niños con dentición temporal y mixta temprana utilizando la técnica de secuenciación de próxima generación (HOMINGS). Infecc. y Microbiol. Clínica 37, 448-453 (2019).

27. Luna-Guevara, M. et al. Diversidad de enterobacterias asociadas a frutos de tomate (Lycopersi-cum sculentum Mill) y suelos de invernadero. Sci. Agropecu. 3, 161-169 (2012).

28. Larrea-Murrell, J., Rojas Badía, M., Lugo, D. \& Heydrich, M. Structure of rapid growth culturable heterotrophic bacterial community in Almendares River, Havana, Cuba. Cuba J Biol Sci Cuba Ciencias Biológicas 8:1-9. http://www.rccb.uh.cu/index.php/RCCB/article/view/284/353. (2020).

29. Vergara-López, L., Diazgranados-Santos, M., Ortiz-Díaz, A., Machacado-Salas, M. \& Rache-Arce, D. Morfotipos bacterianos aislados en el Antiguo Vertedero de Navarro. Editorial USC. 18p. IOP Publishing PhysicsWeb.

https://repository.usc.edu.co/bitstream/20.500.12421/3055/1/CartillaAVN.pdf. Accessed 26 June 2020. (2020).

30. Bodelier, P. Toward understanding, managing, and protecting microbial ecosystems. Front. Microbiol. 2, 80 (2011).

31. Bardgett, R. \& Van Der Putten, W. Belowground biodiversity and ecosystem functioning. Nature 515, 505-511 (2014).

32. Ramirez, K. et al. Biogeographic patterns in below-ground diversity in New York City's Central Park are similar to those observed globally. Proc. R. Soc. B Biol. Sci. 281, 20141988 (2014).

33. Larsen, B., Miller, E., Rhodes, M. \& Wiens, J. Inordinate fondness multiplied and redistributed: the number of species on earth and the new pie of life. Q. Reviw Biol. 92, 229-265 (2017).

34. Delgado-Baquerizo, M. et al. A global atlas of the dominant bacteria found in soil. Science (80-. ). 359, 320-325 (2018).

35. Ahmed, W., Goonetilleke, A. \& Gardner, T. Implications of faecal indicator bacteria for the microbiological assessment of roof-harvested rainwater quality in Southeast Queensland, Australia. Can. J. Microbiol. 56, 471-479 (2010).

36. Galfi, H., Osterlund, H., Marsalek, J. \& Viklander, M. Indicator bacteria and associated water quality constituents in stormwater and snowmelt from four urban catchments. J. Hydrol. 539, 125-140 (2016).

37. Ulea, E., Lipşa, F., Bălău, A., Filipov, F. \& Morari, E. Diversity of soil bacteria as a indicator of soil pollution in Moldavia region, Romania. Environ Eng Manag J 16:879-889. http://omicron.ch.tuiasi.ro/EEMJ/. (2017).

38. Šrut, M., Menke, S., Höckner, M. \& Sommer, S. Earthworms and cadmium - Heavy metal resistant gut bacteria as indicators for heavy metal pollution in soils? Ecotoxicol. Environ. Saf. 171, 843-853 (2019).

39. Metz, M., Sheehan, J. \& Feng, P. C. Use of indicator bacteria for monitoring sanitary quality of raw milk cheeses-A literature review. Food Microbiol. 85, 103283 (2020).

40. Møretrø, T. \& Langsrud, S. Residential Bacteria on Surfaces in the Food Industry and Their Implications for Food Safety and Quality. Compr. Rev. food Sci. food Saf. 16, 1022-1041 (2017).

41. Arévalo-Arbeláez, Á., Bedoya-Urrego, K., Cabarcas-Jaramillo, F. \& Alzate-Restrepo, J. Descripción de la microbiota bacteriana residente en el biosólido generado en la planta de tratamiento de aguas residuales San Fernando. Itagüí, Colombia. Rev. Salud Pública 19, 806-813 (2017).

42. Ye, L. \& Zhang, T. Bacterial communities in different sections of a municipal wastewater treatment plant revealed by $16 \mathrm{~S}$ rDNA 454 pyrosequencing. Appl. Microbiol. Biotechnol. 97, 2681-2690 (2013).

43. Zamora, A., Malaver, N. \& Ramos, J. Análisis funcional de microorganismos: un estimador de diversidad y estructura comunitaria. Acta Biol Venez 32:57-86. https://www.researchgate.net/publication/272492530. (2012).

44. Corrales, L., Romero, D., Macías, J. \& Vargas, A. Bacterias anaerobias: procesos que realizan y contribuyen a la sostenibilidad de la vida en el planeta. Nova 13, 55-82 (2015).

45. Silva-Bedoya, L., Sánchez-Pinzón, M., Cadavid-Restrepo, G. \& Moreno-Herrera, C. Bacterial community analysis of an industrial wastewater treatment plant in Colombia with screening for lipid-degrading microorganisms. Microbiol. Res. 192, 313-325 (2016).

46. Alvariño, C., Navarrete, J., Petit, X. \& Hernández, M. Filtro biológico en el tratamiento de lixiviados. Ciencias Biológicas 41:1-11. http://www.redalyc.org/articulo.oa?id=181220509035. (2010).

47. Wagner, M. \& Loy, A. Bacterial community composition and function in sewage treatment systems. Curr. Opin. Biotechnol. 13, 218-227 (2002).

48. Arango, Y. Microbiología de lodos activados. Hechos Microbiológicos 4:117-122. https://revistas.udea.edu.co/index.php/hm/article/view/21093. (2014).

49. Boothe, D., Smith, M., Gattie, D. \& Das, K. Characterization of microbial populations in landfill leachate and bulk samples during aerobic bioreduction. dvances Environ. Res. 5, 285-294 (2001).

50. Mandic-Mulec, I., Stefanic, P. \& van Elsas, J. Ecology of bacillaceae. The bacterial spore: From molecules to systems. 59-85 (2016). doi:10.1128 /microbiolspec

51. Steinnes, E. Heavy metal contamination of the terrestrial environment from long-range atmospheric transport: Evidence from 35 years of research in Norway. E3S Web Conf. 1, 35001 (2013). 
52. Ghoul, M. \& Mitri, S. The ecology and evolution of microbial competence. Trends Microbiol. 24, 833-845 (2016).

53. Rivett, D. \& Bell, T. Abundance determines the functional role of bacterial phylotypes in complex communities. Nat. Microbiol. 37, 767-772 (2018).

54. Ainsworth, T. et al. The coral core microbiome identifies rare bacterial taxa as ubiquitous endosymbionts. ISME J. 9, 2261-2274 (2015).

55. Ward, D. \& Lariviére, M. Terrestrial invertebrate surveys and rapid biodiversity assessment in New Zealand: lessons from Australia. New Zealand J. Ecol 28, 151-159 (2004).

56. Moreno, J. \& Albarracín, V. Aislamiento, cultivo e identificación de microorganismos ambientales a partir de muestras naturales. Reduca 5:79-93. http://www.revistareduca.es/index.php/biologia/article/view/963/996. (2012).

57. Gómez, M., Vivas, L., Ruíz, R., Reyes, V. \& Hurtado, C. Bacterias marinas nativas degradadoras de compuestos orgánicos persistentes en Colombia. Instituto de Investigaciones Marinas y Costeras - INVEMAR - Santa Marta. 32 p. (Serie de publicaciones generales No. 19).

http://observatorio.epacartagena.gov.co/wp-c. (2006).

58. Moreno, C. Métodos para medir la biodiversidad. Manuales y Tesis SEA 1:84. Dissertation, Universidad Autónoma del Estado de Hidalgo. (2001).

59. Chodak, M., Gołębiewski, M., Morawska-Płoskonka, J Kuduk, K. \& Niklińska, M. Diversity of microorganisms from forest soils differently polluted with heavy metals. Appl. Soil Ecol. 64, 7-14 (2013).

\section{Tables}

Table 1. Characteristics of bacterial morphotypes obtained from the landfill leachate treatment plant

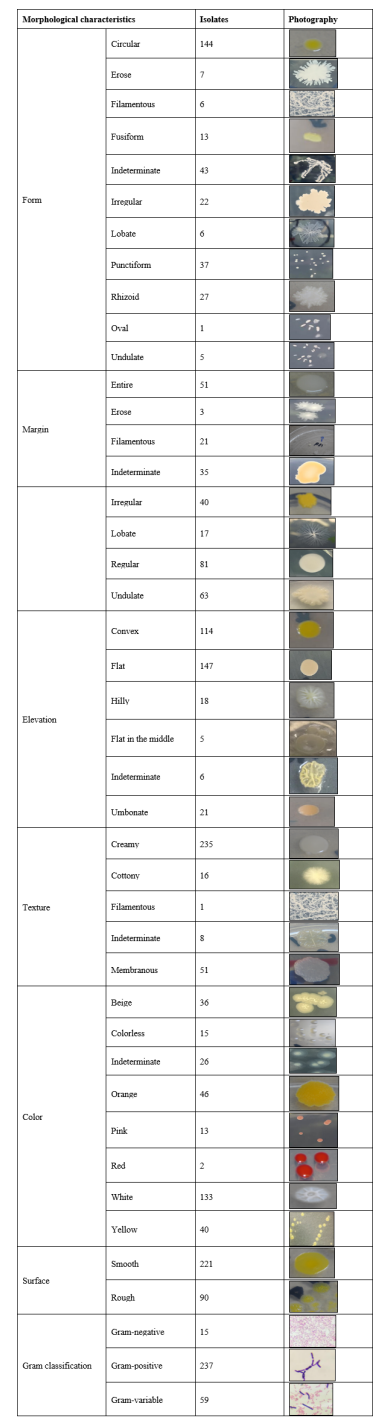

Table 2. Diversity indexes applied to bacterial morphotypes 


\begin{tabular}{|c|c|c|c|c|c|c|c|c|c|c|c|c|c|c|c|c|}
\hline \multirow[t]{2}{*}{ Lagoon } & \multicolumn{4}{|c|}{ First sampling (March) } & \multicolumn{4}{|c|}{ Second sampling (August) } & \multicolumn{4}{|c|}{ Third sampling (October) } & \multicolumn{4}{|c|}{ Global analysis } \\
\hline & D & $\mathrm{H}^{\prime}$ & $\mathrm{J}$ & SChao1 & D & $\mathrm{H}^{\top}$ & $J$ & SChao1 & D & $\mathrm{H}^{\prime}$ & $J$ & SChao1 & D & $\mathrm{H}^{\prime}$ & J & SChao1 \\
\hline L3 & 0.77 & 0.73 & 0.25 & 147 & 0.16 & 2.26 & 0.86 & 39 & 0.15 & 2.45 & 0.63 & 72 & 0.15 & 2.6 & 0.63 & 72 \\
\hline L4 & 0.56 & 1.48 & 0.53 & 100 & 0.28 & 2.2 & 0.64 & 55 & 0.29 & 1.91 & 0.61 & NA & 0.15 & 2.69 & 0.64 & NA \\
\hline L5 & 0.92 & 0.28 & 0.13 & NA & 0.12 & 3.05 & 0.80 & 130 & 0.39 & 1.28 & 0.46 & 34 & 0.31 & 1.68 & 0.41 & 34 \\
\hline L6 & 0.49 & 1.35 & 0.50 & 31 & 0.05 & 3.04 & 0.97 & 48 & 0.11 & 2.76 & 0.86 & 32 & 0.10 & 3.21 & 0.79 & 32 \\
\hline L7 & 0.46 & 1.44 & 0.56 & NA & 0.22 & 2.75 & 0.66 & 153 & 0.21 & 2.16 & 0.57 & 84 & 0.12 & 2.94 & 0.63 & 84 \\
\hline L8 & 0.93 & 0.23 & 0.10 & 18 & 0.09 & 2.87 & 0.87 & 745 & 0.39 & 1.52 & 0.45 & 54 & 0.25 & 1.97 & 0.48 & 54 \\
\hline PL & 0.58 & 1.16 & 0.44 & 74 & 0.06 & 2.9 & 0.95 & 202 & 0.15 & 2.45 & 0.60 & 128 & 0.13 & 2.57 & 0.59 & 128 \\
\hline
\end{tabular}

$\mathrm{D}=$ Simpson index, $\mathrm{H}^{\prime}=$ Shannon index, $\mathrm{J}=$ Pielou's index, SChao1 = Chao1 index, NA= not available

\section{Figures}

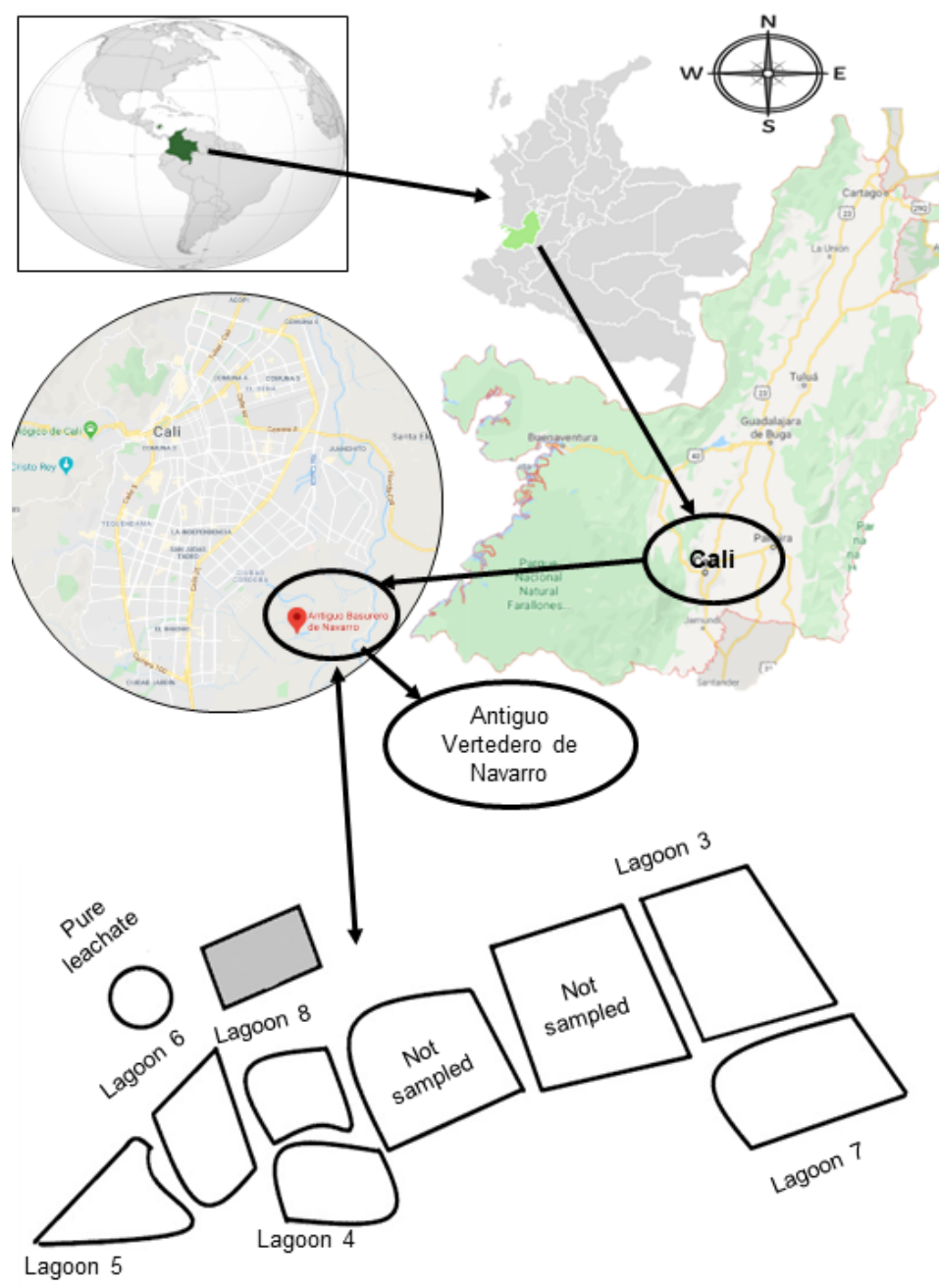

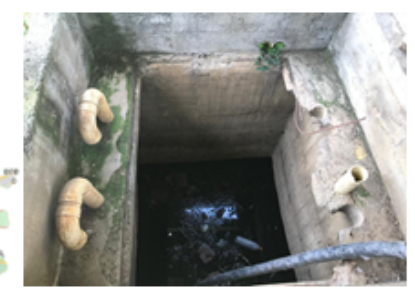

Pure leachate

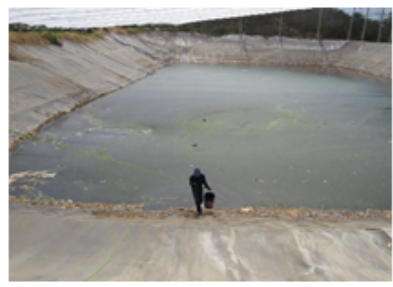

Lagoon 4

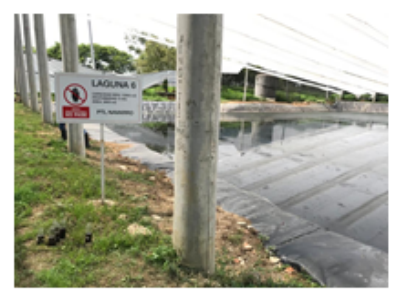

Lagoon 6

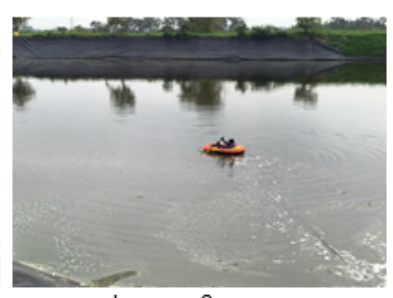

Lagoon 3

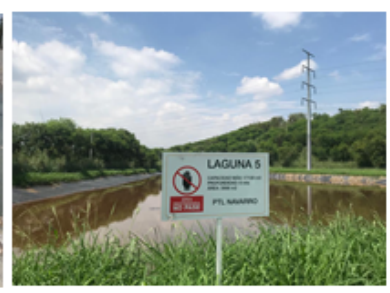

Lagoon 5

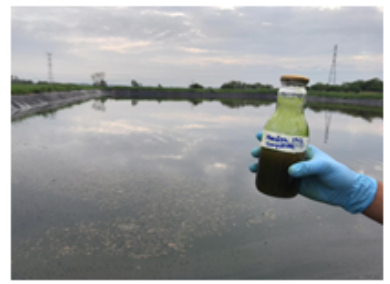

Lagoon 7

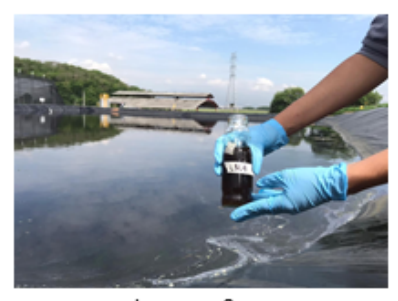

Lagoon 8

\section{Figure 1}

Landfill leachate treatment plant located at Valle del Cauca, Colombia Note: The designations employed and the presentation of the material on this map do not imply the expression of any opinion whatsoever on the part of Research Square concerning the legal status of any country, territory, city or area or of its authorities, or concerning the delimitation of its frontiers or boundaries. This map has been provided by the authors. 


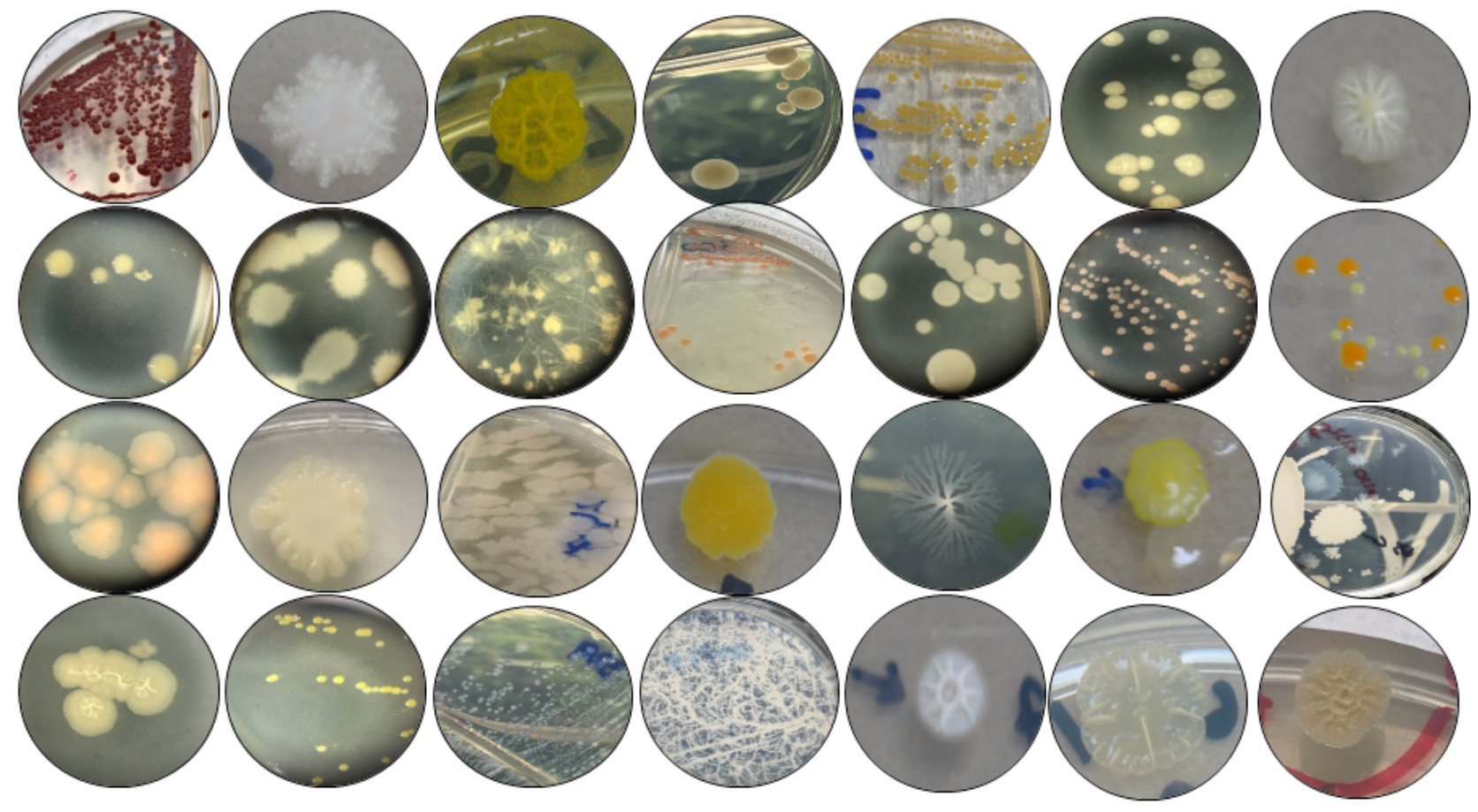

Figure 2

Photography of some bacterial morphotypes obtained from the landfill leachate treatment plant

\section{Bacterial morphotypes}

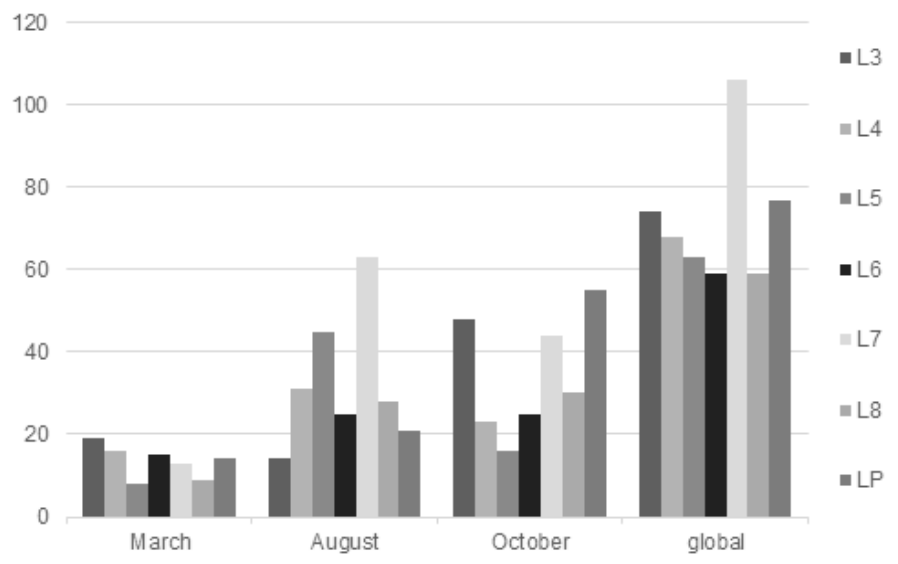

Gram (global )

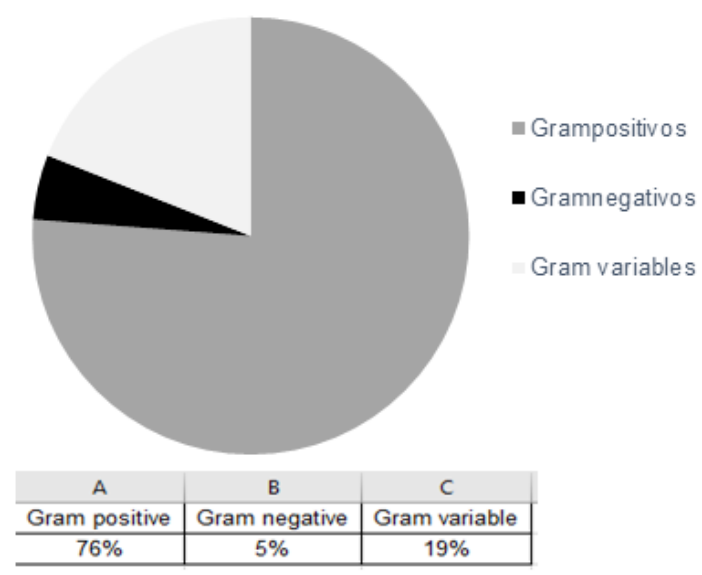

\section{Figure 3}

Number of bacterial morphotypes collected in the three samplings conducted at the studied lagoons and pure leachate and bacterial differentiation based on Gram staining 